\title{
South Africa's role in the Civil War in Russia 1918-1920
}

Cdr W.M. Bisset*

South Africa's role in the Civil War in Russia (1917-1920) has never been fully researched and it is probable that relatively few people are aware that South Africans were among those who fought against the Red Army in 1918-1920.

Although it has not been possible to trace a roll of members of the South African Forces who served in Russia between 1918 and 1920, their autobiographies and letters published in The Nongqai have made it possible to compile an interim report on the subject. However, it is important to note that even if the roll of members of the South African Forces who served in Russia could be traced or compiled from the personnel record cards in the SADF Archives, this would not provide a complete picture because a number of the South Africans who served in Russia had served in the British Forces throughout the Great War.

Whilst South Africa's contribution would seem to have been very slight, the calibre of our servicemen was outstanding. Two had won the coveted Victoria Cross, Great Britain's highest award for an outstanding deed of valour in the face of the enemy, and most had been decorated during the war or were later to receive awards for their services in Russia. Perhaps the most remarkable thing of all is that these South Africans, who were all volunteers, should have been prepared to risk their lives again immediately after they had survived the most terrible war in history.

Fortunately some of the reasons for their seemingly strange and reckless choice have been recorded. Sgt Malcolm McCorkindale who had survived Delville Wood and been wounded five times and gassed three times in the Great War, told a newspaper reporter that he saw a poster in Southampton Docks which bore the inscription 'Russia needs men like you'. He seized this 'offer of more adventure and another fight' and served for 14 months in Russia with the Cossacks on the Dwina River and in the Salamango Forest and with the British Machine Gun Corps.

Capt (later Col Sir) Hugh Boustead records in his autobiography The Wind of Morning that the SA Infantry Brigade in France received requests for officers to serve in a mission to assist the White Russian Armies in their war with the Bolsheviks. Volunteers were required to complete an application form and were informed that they would be sent where the need was greatest. Capt Boustead volunteered at once because he found 'the ardours and endurances and dangers of the past years, shared in company with men whom he admired greatly stimulating in spite of the horrors of the Western Front'. ${ }^{1}$

He served in South Russia where he wore his South African Scottish uniform. In sharp contrast he records that 'from General down to Plastuni, the dress order of the day (for the White Forces) was sacking, small caps which gave no protection from the sun and, for at least half the men, no boots'.

Capt R. Beverley, DSO, MC mentions a far more practical reason for serving in Siberia in a letter to his erstwhile chief, Brig gen F.S. Dawson. Capt Beverley had forseen that officers with temporary commissions would have to revert to their substantive ranks after the war and wrote that he had 'anticipated it all by volunteering to stay on here (in Siberia) as long as possible'. ${ }^{3}$

Lt col W.J. Clarke, OBE, late 2nd SAMR, wrote to the Editor of The Nongqai that the British officer experts were in North Russia 'to help the Russians and to save Russia for them'. ${ }^{4}$ Lt col Clarke was responsible for mounted infantry training and described the Russian soldier as 'one of the best soldiers in Europe'. ${ }^{5}$

Lt col (later Maj gen) K.R. van der Spuy has described his service in North Russia in his autobiography Chasing the Wind. Early in 1918 he was invited to form and command an air force unit to support the Allied Forces in North Russia based at Archangel. The officers whom he selected included 'three South Africans, three Australians, two Canadians and a few men who had had experience in the colonies and dominions'. The reason for this choice was that he had found that 'such men were well fitted to adapt themselves to strange and severe conditions'. ${ }^{6}$ 


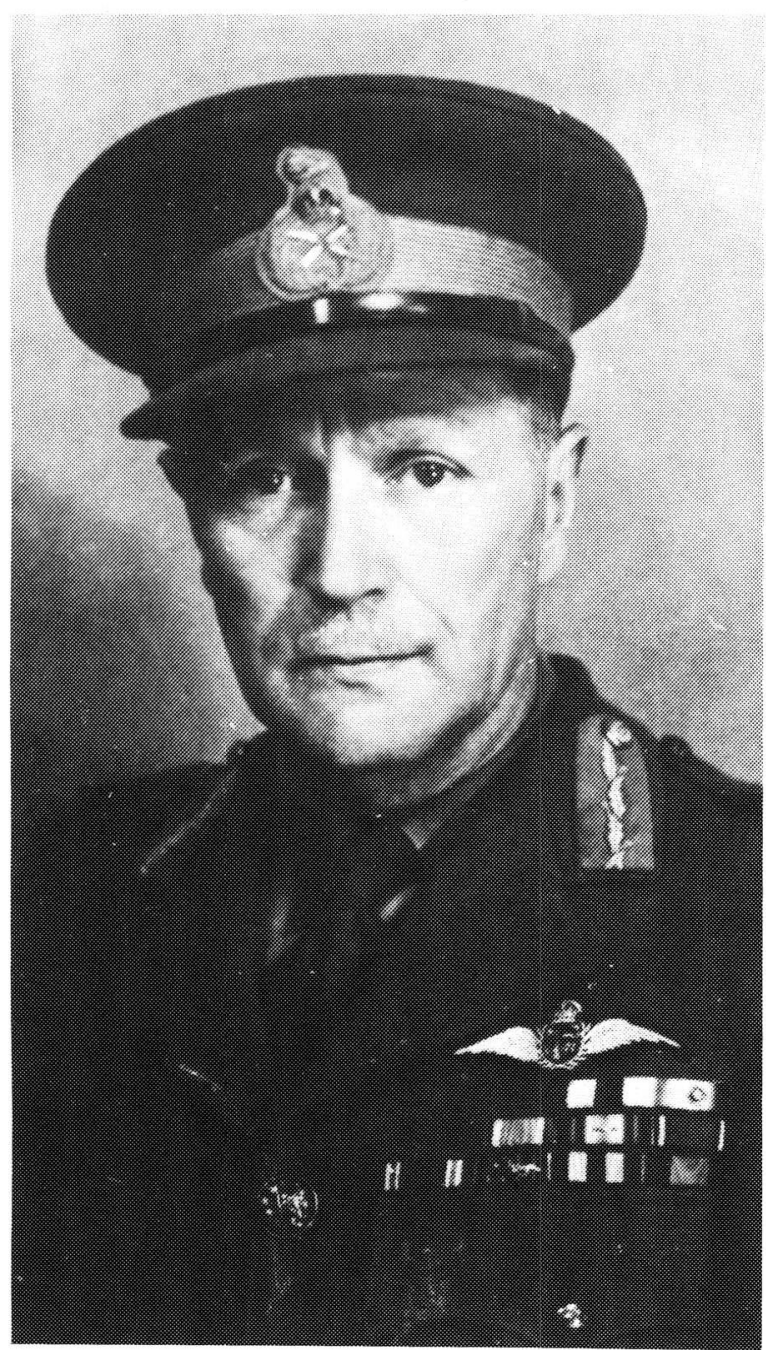

Maj gen K.R. van der Spuy

Maj gen van der Spuy was one of the fortunate few who had served continuously from 1914 and survived. After service as an SA Aviation Corps pilot attached to the Royal Flying Corps with the British Expeditionary Force in France in 1914 he had served in German South West Africa and German East Africa and it is hardly surprising that his luck finally ran out in North Russia. The engine of his Camel single seater failed over Bolshevik territory and he was taken prisoner.

Another remarkable South African officer who served in North Russia was Lt col H.H. Jenkins who had commanded the 1st Battalion SAI on the Western Front in France. In North Russia he commanded the 46th Royal Fusiliers. During the offensive against the Bolsheviks he commanded three columns on the right bank of the Dwina River which inflicted a severe defeat on the enemy and captured over 1000 prisoners, nine guns, many machine guns, trench mortars and stores. ${ }^{7}$
Capt Thomas G Macfie, 4th Battalion SAI was awarded the Distinguished Service Order, for his service in North Russia. The citation reads: 'On 2 June 1919 he was near the 18-pounder position on his way to the observation post. He collected and organized some infantry at this point. $\mathrm{He}$ then went back to Priluk, rallying and encouraging Russian infantry who were disorganized and himself led a counter-attack against Priluk, which was recaptured together with all the guns. The success was due to his marked gallantry and ability to command. ${ }^{18}$

When the thaw came in May 1919 the Archangel Force was relieved and sent home. Although it was Maj gen Sir Edmund Ironside's wish that they should receive a special award for their service in Russia and the Arctic Medal with its appropriate white ribbon had been suggested, this proposal came to nothing. ${ }^{9}$ Clasps for the British War Medal 1914-1920 were considered by the British Service Departments but were not approved on account of the cost. Capt R. Beverley was still in Siberia on 7 January 1920 but wrote that he expected to return to England within three weeks and return to Africa if he could not get another post somewhere else in Russia. $^{10}$ Lt L.R. Heydenrych who served in South Russia did not return home to Cape Town until 23 October 1920

Despite the harshness of the Russian winter and the growing prowess of the Red Army, South African officers were able to make a valuable contribution to the operations of the Allied and White Armies which is well illustrated by the important posts which they held and the awards they received.

* Cdr W.M. Bisset is S01 SADF Museums Service.

\section{References}

1. Col Sir Hugh Boustead, The Wind of Morning, London, 1971, p.47.

2. Ibid., p.52.

3. 'Russia in Revolution' in The Nongqai, May 1920, p.233.

4. 'From the Arctic Circle' in The Nongqai, November 1918, p.502.

5. Ibid.

6. Maj gen K.R. van der Spuy, Chasing the Wind, Cape Town, 1966, p.112.

7. Sir O'Moore Creagh and E.M. Humphries, The VC and DSO, Vol III, p.278.

8. London Gazette, 3 October 1919.

9. Field Marshal Lord Ironside, Archangel 1918-1919, London, 1953, p. 149 .

10. 'Russia in Revolution' in The Nongqai, May 1920, p.234

The writer gratefully acknowledges the valuable help received from It J.L. Snider of the Military Information Bureau. 


\begin{tabular}{|c|c|c|c|}
\hline Surname & $\begin{array}{l}\text { Rank and } \\
\text { initials }\end{array}$ & $\begin{array}{l}\text { Honours and Previous unit } \\
\text { or unit in Russia }\end{array}$ & Honours for service in Russia \\
\hline Albu & Capt W.G. & RAF & $\begin{array}{l}\text { Order of Stanislas 2nd Cl, North } \\
\text { Russia }\end{array}$ \\
\hline Beverley & Capt R. & $\mathrm{DSO}, \mathrm{MC}$, late SAI & Siberia \\
\hline Boustead & Capt J.E.H. & $\begin{array}{l}\text { late SA Scottish attd Gen } \\
\text { Denitein's Army }\end{array}$ & $\begin{array}{l}\text { Bar to MC, Order of St. Vladimir, } \\
\text { South Russia }\end{array}$ \\
\hline Browne & T/Maj C.M. & $\begin{array}{l}\text { MC, Gen List, SA Forces, } \\
\text { British Military Mission South } \\
\text { Russia }\end{array}$ & OBE, despatches, South Russia \\
\hline Clarke & Lt Col W.J. & OBE, late 2nd SAMR & despatches, North Russia \\
\hline Dodgson & Capt & Intelligence officer, RAF & North Russia \\
\hline Epstein & Lt M.G. & RAF & North Russia \\
\hline Featherstone & T/Capt C & $\begin{array}{l}\text { Gen List attd } 241 \text { Trench } \\
\text { Mortar Bty }\end{array}$ & MC, North Russia \\
\hline Fraser & Maj & late Border Mounted Rifles & North Russia \\
\hline Green & Lt L.L. & $\begin{array}{l}\text { MC, Rifle Brigade attd } 46 \mathrm{Bn} \\
\text { Royal Fusiliers }\end{array}$ & DSO, Archangel, North Russia \\
\hline Gwatkin & T/Capt R.D.S. & RFA (Lt, SA Forces) & MBE, despatches, Dunsterforce \\
\hline Haselden & Lt Col F. & $\mathrm{DSO}, \mathrm{MC}$, late SAI & North Russia (wounded) \\
\hline Heydenrych & Lt L.R. & $\begin{array}{l}\text { RNVR (SAD) Seconded RN, } \\
\text { Naval Secretary, British } \\
\text { Military Mission, Taganrog }\end{array}$ & $\begin{array}{l}\text { Orders of St Anne and St } \\
\text { Stanislas, 4th Class, South } \\
\text { Russia }\end{array}$ \\
\hline Jenkins & Lt Col H.H. & $\begin{array}{l}\text { DSO, late SAI, OC 46th Royal } \\
\text { Fusiliers }\end{array}$ & $\begin{array}{l}\text { CMG, despatches, Order of St } \\
\text { Anne, 2nd } \mathrm{Cl} . \text { North Russia }\end{array}$ \\
\hline Kinkead & Flt Lt S.M. & DSO and Bar, DFC, RAF & $\begin{array}{l}\text { DSO, Orders of St Anne, St } \\
\text { Stanislas, St George and St } \\
\text { Vladimir, South Russia }\end{array}$ \\
\hline Knowles & Lt Col & & North Russia \\
\hline Lunn & Capt W.S. & $\mathrm{MC}$, late SAHA, RE & Caucasus, South Russia \\
\hline Macfie & Capt T.G. & $\mathrm{MC}$, late $4 \mathrm{SAl}$ & $\begin{array}{l}\text { DSO, despatches, Archangel, } \\
\text { North Russia }\end{array}$ \\
\hline McCorkindale & Sgt M. & $\begin{array}{l}\text { Cossacks and Machine Gun } \\
\text { Corps }\end{array}$ & $\begin{array}{l}\text { Despatches and Order of St } \\
\text { George, North Russia }\end{array}$ \\
\hline MacLeod & Lt Col D.M. & $\begin{array}{l}\text { DSO, MC, DCM, late SAI, OC } \\
\text { 2nd Hampshire Regt }\end{array}$ & Order of St Anne, 2nd Cl. \\
\hline Notcutt & Capt H.J. & MC, Royal Garrison Artillery & $\begin{array}{l}\text { Order of St Anne, 2nd Cl., North } \\
\text { Russia }\end{array}$ \\
\hline Reid & Capt O.A. & VC & Russia \\
\hline Sherwood-Kelly & Lt Col J. & $\begin{array}{l}\text { VC, CMG, DSO, OC 2nd } \\
\text { Hampshire Regt }\end{array}$ & Archangel, North Russia \\
\hline Stewart & 2nd Lt & Ex Natal Police & $\begin{array}{l}\text { Commissioned for gallantry, } \\
\text { North Russia }\end{array}$ \\
\hline Van der Spuy & Lt Col K.R. & MC, RAF, OC Elope Force & $\begin{array}{l}\text { Orders of St George and St } \\
\text { Vladimir, North Russia }\end{array}$ \\
\hline
\end{tabular}

